TTR

Traduction, terminologie, rédaction

\title{
On the Translation of Otherness: The Univocal Case of Will Grayson, Will Grayson
}

\section{Guillermo Badenes}

Volume 32, numéro 2, 2e semestre 2019

La politique des microcentres : la traduction dans des contextes " mineurs " comme transfert culturel complexe

The Politics of Micro-Centers: Translation in "Minor" Contexts as Complex Cultural Transfer

URI : https://id.erudit.org/iderudit/1068906ar

DOI : https://doi.org/10.7202/1068906ar

Aller au sommaire du numéro

\section{Éditeur(s)}

Association canadienne de traductologie

\section{ISSN}

0835-8443 (imprimé)

1708-2188 (numérique)

Découvrir la revue

Citer cet article

Badenes, G. (2019). On the Translation of Otherness: The Univocal Case of Will Grayson, Will Grayson. TTR, 32(2), 131-157. https://doi.org/10.7202/1068906ar

\section{Résumé de l'article}

$\mathrm{Au}$ cours des vingt dernières années, après que le mouvement libérationniste LGBT+ eut fait entendre de nouvelles voix et réalisé des gains sur le plan social, renversant des décennies d'exclusion, la littérature gay a souvent mis l'accent sur les histoires de jeunes dans le but d'inculquer des valeurs positives aux générations futures. Le monde de l'édition grand public en espagnol a pris du retard sur le mouvement LGBT+, publiant peu de littérature queer et favorisant les auteurs canoniques. La critique de la traduction des marges culturelles soulève des questions concernant les voix de l'altérité et met en évidence la visibilité des traducteurs (et des maisons d'édition) en tant que facteurs subjectifs dans le processus de traduction. L’analyse idéologique de la traduction littéraire peut identifier le rôle des traducteurs en tant que médiateurs interculturels qui utilisent des stratégies qui accentuent ou diminuent le caractère LGBT+ des textes. Le roman de jeunesse Will Grayson, Will Grayson, écrit par John Green et David Levithan, présente un défi intéressant du point de vue des différentes identités discursives qui s’y jouent. Le fait qu'il ait été traduit par Noemí Sobregués seule appelle une analyse approfondie des stratégies utilisées pour représenter la dualité du texte en termes idiolectaux. En utilisant les outils proposés par Keith Harvey (2000), cet article se concentre sur l'analyse du rôle de la traductrice dans la version espagnole du roman, dans le contexte de ce que recherchent les maisons d'édition en matière de littérature LGBT+, c'est-à-dire soit la publication de versions édulcorées acceptables pour le grand public, soit la queerification de leur catalogue et, peut-être, du canon au sens large.
Ce document est protégé par la loi sur le droit d'auteur. L'utilisation des services d'Érudit (y compris la reproduction) est assujettie à sa politique d'utilisation que vous pouvez consulter en ligne.

https://apropos.erudit.org/fr/usagers/politique-dutilisation/ 


\title{
On the Translation of Otherness: The Univocal Case of Will Grayson, Will Grayson
}

\author{
Guillermo Badenes \\ Universidad Nacional de Córdoba
}

\begin{abstract}
Over the past twenty years, after the LGBT+ liberationist movement has managed to make new voices heard and had certain social gains, partly overturning decades of exclusion and segregation, gay literature has often focused on the stories of young men and women as a form of instilling positive values upon the future generations. The mainstream publishing world in Spanish has sometimes lagged behind LGBT+ times, publishing little queer literature and favoring mainly canonical authors. Translation criticism from the cultural margins raises questions regarding the voices of alterity and, in this respect, it highlights the visibility of translators (and publishing houses) as subjective factors in the translation process. The ideological analysis of literary translation may identify the role of translators as intercultural mediators who use strategies that accentuate or subdue the LGBT+ character of the texts they translate. The young-adult, gay novel Will Grayson, Will Grayson, written by John Green and David Levithan, presents an interesting challenge from the point of view of the separate discursive identities at play in it. Nonetheless, the novel was solely translated by Noemí Sobregués, a situation calling for closer analysis to revise the strategies used to represent the duality of the text in terms of idiolectal authorship. Using the tools provided by Keith Harvey (2000), this paper focuses on the analysis of the role of this translator in the rendition of the novel in Spanish, in the larger context of what it is that publishing houses seek when they publish LGBT+ literature: either to portray watered-down versions palatable to mainstream readerships, or to queerify their publishing catalogues, and thence, possibly, the canon at large.
\end{abstract}

Keywords: queer translation, young-adult literature, assimilation, queerification, heteronormativity

\section{Résumé}

Au cours des vingt dernières années, après que le mouvement libérationniste LGBT+ eut fait entendre de nouvelles voix et réalisé des gains sur le plan social, renversant des décennies d'exclusion, la littérature gay a souvent mis l'accent 
sur les histoires de jeunes dans le but d'inculquer des valeurs positives aux générations futures. Le monde de l'édition grand public en espagnol a pris du retard sur le mouvement LGBT+, publiant peu de littérature queer et favorisant les auteurs canoniques. La critique de la traduction des marges culturelles soulève des questions concernant les voix de l'altérité et met en évidence la visibilité des traducteurs (et des maisons d'édition) en tant que facteurs subjectifs dans le processus de traduction. L'analyse idéologique de la traduction littéraire peut identifier le rôle des traducteurs en tant que médiateurs interculturels qui utilisent des stratégies qui accentuent ou diminuent le caractère LGBT+ des textes. Le roman de jeunesse Will Grayson, Will Grayson, écrit par John Green et David Levithan, présente un défi intéressant du point de vue des différentes identités discursives qui s'y jouent. Le fait qu'il ait été traduit par Noemí Sobregués seule appelle une analyse approfondie des stratégies utilisées pour représenter la dualité du texte en termes idiolectaux. En utilisant les outils proposés par Keith Harvey (2000), cet article se concentre sur l'analyse du rôle de la traductrice dans la version espagnole du roman, dans le contexte de ce que recherchent les maisons d'édition en matière de littérature LGBT+, c'est-à-dire soit la publication de versions édulcorées acceptables pour le grand public, soit la queerification de leur catalogue et, peut-être, du canon au sens large.

Mots-clés : traduction queer, littérature de jeunesse, assimilation, queerification, hétéronormativité

\section{Introduction}

Will Grayson, Will Grayson, a novel published in 2010 and directed mainly at young adults, was written by two authors, John Green and David Levithan. The authors' goal was to cooperatively produce the text following a dialogical creative process. After agreeing to write the story of two high school students by the same name, Green wrote the first chapter setting the grounds for the characters, the general storyline, tone, and atmosphere, and other aspects that would frame the work. In turn, after reading that first chapter, Levithan embarked on the continuation of the novel from the standpoint of the "other" Will Grayson to whom the novel refers: another character in another context, created in a different tone, and with a different narrative voice. Thus, chapter by chapter, as the two Will Graysons' lives progressed, the plot advanced. The narrative styles, the tones of the respective characters, the atmospheres built, the personalities developed, and the rewriting of the reciprocal characters (as both authors took each other's creation and rewrote them according to their own plot agendas) constitute an authorial plurivocality that enriches the analysis of the source text as much as that of the translation by Noemí Sobregués for the publishing house Nube de Tinta. 


\section{Will Grayson Number 1}

The premise of Will Grayson, Will Grayson is as appealing as uncomplicated: Will Grayson is an ordinary heterosexual young man who tries his best to go unnoticed, and whose life is guided by two principles: "1. Don't care too much. 2. Shut up" (Green and Levithan, 2010a, p. 5). However, his best friend, Tiny Cooper, "may be the world's largest person who is really, really gay" (ibid., p. 3), which makes it difficult for him to be inconspicuous at school. This Will Grayson, the brainchild of John Green ${ }^{1}$, occupies the odd-numbered chapters, which have a notably camp style.

In her pioneer article "Notes on Camp," Susan Sontag defines camp as a sensibility that loves the unnatural, artifice and exaggeration, that converts the serious into the frivolous, that sees the world as an aesthetic phenomenon, not in terms of beauty, but in terms of its degree of artifice, of stylization (1961, pp. 275-277). In this regard, certain features of Green's chapters, such as irony, playfulness, extravagance, and a linguistic interest (through metalanguage, figures of speech or neologisms), contribute to highlight their camp style. According to Sontag, camp "is the farthest extension, in sensibility, of the metaphor of life as theater" (ibid., p. 280). Not surprisingly, then, a large portion of the novel revolves around the fact that Tiny is preparing an autobiographical musical production entitled Tiny Dancer. Musicals represent a typical camp form, tackling serious issues trivially by choreographing everyday-even traumatic-life situations- to flamboyant music.

Sontag's understanding of camp as a sensibility has been criticized for her idea that "homosexuals, by and large, constitute the vanguard — and the most articulate audience-of Camp" (ibid., p. 290), entailing that camp may often (but not always) be queer. A different perspective posits that "Camp is political; Camp is solely a queer (and/or sometimes gay and lesbian) discourse; and Camp embodies a specifically queer culture critique" (Meyer, 1994, p. 1). Considering Green's activism in LGBT+ issues such as gay marriage, this point of view informs the importance of the camp style of the novel, and supports the need to analyze the effectiveness of the strategies used by the translator of the novel.

1. John Green is the best-selling young-adult author of Paper Towns (2008) and The Fault in Our Stars (2012). He was named one of Time magazine 100 most influential artists in 2014. 
Green's chapters are rich in irony. For instance, when Will goes to one of the rehearsals of Tiny's musical, Will the narrator reflects: "And, since they are theater people, they are talking. All of them. Simultaneously. They do not need to be heard; they only need to be speaking" (Green and Levithan, 2010a, p. 161). Playfulness is also reflected in the use of intertexts such as Will's understanding of the way teenagers reinterpret the classics- "[s]hall I compare thee to a summer's day' becomes 'u r hawt like august" (ibid., p. 159)—, or in the grammatical interest in language. After a falling-out between Will and Jane, Will reflects: “'[n]othing happened,' I say, and then correct myself. 'Nothing didn't happen"' (ibid., p. 51).

Will Grayson uses a teenage sociolect loaded with grandiloquent words which are juxtaposed with high school slang. This linguistic fluctuation confers a certain comedic tone to the text, and underlines the process of identity development which takes place during adolescence. In fact, this strategy may contribute to self-identification on the part of the young readership toward which the novel is geared. Will is certain that "Tiny was in love with Zach during precalc. But forty-seven minutes have passed since his proclamation, so maybe he's changed gears. Tiny has had about 3,900 boyfriends-half of them Internet-only" (ibid., p. 6). As with this hyperbole, there are instances of many other figures of speech such as the following:

- litotes: "Honestly, none of them ever seemed to like me, but they were around, which isn't nothing” (ibid., p. 4);

- paradox and alliteration: "all kindness is cruelty, all selfishness generous, all care callous” (ibid., p. 78);

- catalogue: "There's the getting up, and the showering, and the school, and the miracle of Tiny Cooper and the desk [...]." (ibid., p. 38)

These enrich and stylistically complexify Green's chapters.

Additionally, the interest in language in these chapters is reflected in the extended use of neologisms such as "arelantionshipal" (ibid., p. 42), "unhot" (ibid., p. 43), "absuh-freakin'-lutely" (ibid., p. 45), "crescendoing" (ibid., p. 86), or "sobutand" (ibid., p. 190). There are even cases of metalanguage, expressed especially in the constant text messaging, the epitome teenage mode of communication:

Jane: Hey!

Me: Hey. 
Jane: Sorry, that might have been inappropriate exclamation point use.

Me: Ha. All good. (ibid., p. 40)

These features contribute to grant Green's chapters their camp style and are frequently combined with numerous references to the contemporary teenage lifestyle. For example, in chapter one, Will, Tiny and Jane- "who may or may not be gay" - go to a rock concert that does not live up to their expectations, which makes Jane decide that they have to leave: "We gotta bolt. This band is like a root canal sans painkiller" (ibid., p. 18). The irony, the stylization and refinement of the Shakespearean/French word, the hyperbole, and the registerswitching make up the essence of camp that dominates Green's style in the novel. It is interesting to note that the chapters that are rich in this style are those that portray the life of the Will Grayson who is straight.

Similarly, Green's chapters offer ample references to current issues that are relevant to the LGBT+ community, which comes to reaffirm Moe Meyer's idea that

Camp [...] is queer. It can be engaged directly by the queer to produce social visibility in the praxis of everyday life, or it can be manifested as the camp trace by the un-queer in order [...] to provide queer access to the apparatus of representation. (1994, p. 5)

In his book The Pleasure Principle, Michael Bronsky offers an exploration of the existing tensions in LGBT+-heterosexual relations, which go from the heterosexual fear to homoeroticism and gay culture (and the pleasure they entail), to the envy and desire to enjoy that liberty and freedom $(2000$, p. 2). This is a pressing issue that rises today in the United States, for example, in the debate on the use of public restrooms by the trans community, who in some states are oftentimes forced to use bathrooms according to their genitalia instead of their gender identity, or in the controversy that was raised by the website The Daily Beast when it published an article exposing the sexuality of athletes in the Rio 2016 Olympic Games (Editorial Staff, 2016). In Will Grayson, Will Grayson, the narrator recalls a rhyming couplet from Tiny's musical—-"The locker room isn't porn for me/'cause you're

2. The leitmotif "who may or may not be gay" in reference to the character of Jane, repeated throughout the first chapters of the novel, is introduced here because the translation of the text portrays her as a homosexual, a term that will later be contested in this article. 
all too damned pimple-ey" (Green and Levithan, 2010a, p. 39)—in reference to the heterosexual fear of having gays in locker rooms. In another passage, Will calls Tiny a "cocksucker," to which Tiny replies: "You can't call me a cocksucker, Grayson, because A. It's not an insult, and B. You know I'm not one. Yet. Tragically" (ibid., p. 46). As a novel geared toward young readers, there is at times a certain pedagogic tone intended to note slurs that should not be used due to their offensive load as well as identity issues that go beyond sexual practices. Tiny, as most of the other teenage characters in the novel, is not sexually active yet. Therefore, he jokingly protests the fact that he has not engaged in fellatio while he indicates that if (or when) he decided to do so, his homoerotic sexual practices should not be used as an insult. As we shall see in further examples, when I discuss Sobregués' translation, there are lexical elements in the source text that make reference to and are meant to instill pride in the LGBT+ community, elements that, in the translation, are used as slurs, contradicting the very ideas that Green imbues in the example above.

The novel presents concepts such as the right to the expression of one's own sexuality, and challenges heteronormative canons. Even though it presents a very specific social group of adolescents, namely suburban middle/upper-middle class youths, there are no references to ethnic backgrounds. While this may hamper discussing a diverse LGBT+ experience, it may also allow readers of varied backgrounds to identify with different forms of the LGBT+ experience: Tiny is large and campy; Levithan's Will Grayson is an introverted angry, young man; Jane may or may not be a lesbian, and Tiny's assortment of would-be boyfriends range from jocks to nerds, to geeks, and all other shades in between.

While the novel could be accused of fostering an assimilated vision of the LGBT+ experience, it is important to emphasize its target readership, i.e., adolescents. While popular entertainment, which is the creation of mass pleasure, usually aims at revitalizing "the status quo in sharp relief to the more radical function of pushing or transgressing the boundaries of social thought and experience" (Bronski, 2000, p. 28), the mere fact of presenting LGBT+ characters as the protagonists of the novel in the context of the highly governed (by PTAs, libraries, school districts and other mechanisms of control) literary market represents a feat of transgression in itself. The ultimate goal of queer culture is to push the envelope of traditional cultural values, which this product attains against heteronormative virtues. 
Will Grayson, Will Grayson may be said to have broken new ground in a trend in which "[i]t is also becoming more common to find romance, fantasy, and paranormal books that include characters who just happened to be gay" (Kehe, 2010, n.p.). Additionally, its campiness is a destabilizing factor that adds to its queer character considering that "[c]amp [...] is the production of queer social visibility" (Meyer, 1994, p. 5). I will argue that its intended readership constitutes a transgression on its own, conforming its queer spirit. "The power of gay culture is the power to critique mainstream culture, particularly in areas of sexuality and gender, to be able to speak the 'truth' or offer an alternative model" (Bronski, 2000, p. 56). This very intention of presenting a different outlook of society (and sexuality) is what has historically been considered a threat to hegemonic mores.

\section{Will Grayson Number 2}

The "other"Will Grayson, the result of David Levithan's penmanship, occupies the even-numbered chapters of the novel. Levithan, also an LGBT+ activist and best-selling author of young-adult novels that showcase gay characters, has proved that there is a huge market niche for LGBT+ novels. He believes that "[1]anding as high on The Nerw York Times list as we did with 'Will Grayson, Will Grayson' made a big statement to the children's publishing world that gay characters are not a commercial liability" (qtd. in Kehe, 2010, n.p.). Also narrated in the first person, these chapters offer a style different from Green's. Here, irony gives way to sarcasm - to the point of viciousness at times-written from the start in lower-case letters because, as Levithan explains to Green in the interview that accompanies the English version of the novel, this Will Grayson regards himself selfdeprecatingly:

$\mathrm{He}$ is a lowercase person. He is used to communicating online, where people are encouraged to be lowercase people. His whole self-image is what he projects in that space, and his one comfortable form of communication is when he is anonymous and sending instant messages. (Green and Levithan, 2010b)

There are a few similarities between Levithan's and Green's prose, similarities that perhaps multiply in the central chapters of the novel, but which divert once more toward its final chapters. For instance, there is a whimsical use of grammar-which may perhaps resemble Green's playful use of the language-, "i don't believe in that. i believe against that" (Green and Levithan, 2010a, p. 23). Similarly, Levithan's 
chapters are rich in neologisms: "crappaccino" (ibid., p. 24); "witchtwat-frigid chicago suburb" (ibid., p. 27); "girling out" (ibid., p. 58); "i'm not feeling very mathletic. maybe you should find a subletstitute" (ibid., p. 96); "a trip with the calcsuckers" (ibid., p. 98); "if it's a girl, you should name her logorrhea. if it's a boy, go for trig" (ibid., p. 101). There are certain examples of metalanguage akin to the ones in Green's sections:

now, if anyone ever uses lol with me, i rip my computer right out of the wall and smash it over the nearest head. i mean, it's not like anyone is laughing out loud about the things they lol. i think it should be spelled loll, like a lobotomized person's tongue does. loll. loll. i can't think anymore. loll. loll! (ibid., p. 28)

One also notices a certain interest in the creative process of the literary author, even though, in this case, it is Gothic poetry instead of the light-hearted musical production of Tiny's play, which takes away any camp from Levithan's style:

\author{
hang me \\ like a dead rose \\ preserve me \\ and my petals won't fall \\ until you touch them \\ and i dissolve (ibid., p. 63)
}

Green's irony has been substituted here for Levithan's sarcasm, "in our fine institution of lower learning" (ibid., p. 25), or "sorry, geniuses, there's no such thing as a fuck cure. a fuck cure is like the adult version of santa claus" (ibid., p. 66). Levithan builds this Will Grayson with teenage angst, unfettered lividity, and social discontent:

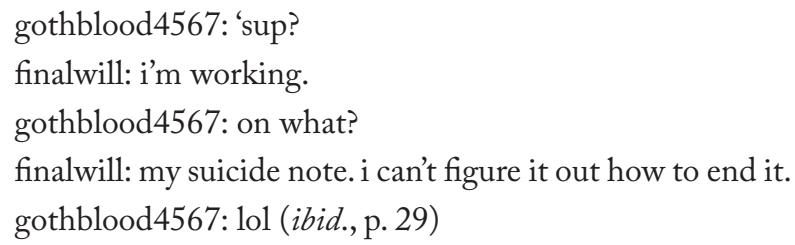

The even-numbered chapters offer a type of telegraphic style that matches this Will Grayson's personality, where dialogues are brief and choppy, "me: give me some coffee./maura: get your own fucking coffee" (ibid., p. 24). Unlike the first Will Grayson, this one-who is gayseems to be angry with his life. He has been medicated for depression, and he relates to his peers through permanent exasperation: "god 
bless the mood equalizers. and all moods shall be created equal. i am the fucking civil rights movement of moods" (ibid., p. 67). It is also possible to observe how intertexts have a more political stance here. Even when hypotexts belong to pop culture, they carry with them prominent social criticism. For instance, this Will writes instant text messages to his virtual boyfriend Isaac, and asks him:

boundbydad: u there?

boundbydad: I'm wishin'

boundbydad: and hopin'

boundbydad: and prayin' (ibid., p. 67)

In spite of the fact that the original Burt Bacharach song referenced here, made popular by Dusty Springfield in the 1960s, offers a highly heteronormative vision of gender, the immediate teenage reference might actually be the version of the song included in the opening titles of the film My Best Friend's Wedding (Hogan, 1997), where it was performed with irony by bisexual singer and activist Ani Di Franco, known for her commitment to the plight against sexism and homophobia, and her advocacy of sexual rights. Thus, the reference becomes sarcastically critical of heteronormative, hegemonic views.

The narrative style of Levithan's chapters makes scarce use of stylistic devices, which are mostly reduced to puns- "why do you have to fix the salad? who broke it? i didn't touch it. did you break the salad, mom? If you did, YOU'D BETTER FIX IT!” (ibid., p. 200)—, and are usually loaded with irony and sarcasm: "every morning i pray that the school bus will crash and we'll all die in a fiery wreck" (ibid., p. 23). Nonetheless, there is also a frequent use of binary oppositions such as "she'll be able to get more money for my tragic death than she would've ever made in my tragic life" (ibid., pp. 23-24), or "she's going to say I led her on, when the truth is I was only holding her off" (ibid., p. 65), which contribute to the creation of a character that constantly displays an obsessive-compulsive behavior filled with teenage anxiety and belligerence that makes him regard his life in terms of opposites, either in black or white.

\section{Will Grayson - Will Grayson}

As the result of this singular creative process, the novel allows readers to enjoy two particular, divergent narrative styles. Even when both Will Graysons meet in chapter seven and their stories begin to intertwine, both writers continued reacting to the plot proposals 
made by each other. Furthermore, despite the fact that there is a certain stylistic symbiosis between Green and Levithan halfway through the novel (Green's Will Grayson becomes braver and more confrontational, while Levithan's Will Grayson adopts a less stripped or minimalistic locution taking up a friendlier tone), both authorial styles soon diverge once more towards the end of the novel. This is one of the reasons that makes its analysis interesting from the point of view of the translation problems that the distinct dictions supply.

Three hypotheses guided my analysis of Noemí Sobregués' translation of Will Grayson, Will Grayson. First, that queer translation criticism showcases the issues of voices silenced by mainstream literature, and highlights the visibility of the translator as a subjective agent in the translation process. Secondly, that the ideological analysis of the translation of this LGBT+ novel enables us to recognize the role of the translator as a political agent. Finally, that the translation decisions made by the publishing house (as the gatekeeper of the literary canon) determine the literary product as either inclusive of silenced voices or as a promoter of mainstream discourses.

Similarly, a series of objectives guided my work, the main one being to identify, in the translation, strategies centered on the authors and strategies centered on the translator. This objective was broken down in four specific ones: using tools provided by translation studies to perform the analysis of this LGBT + translation; noting translation problems with respect to the cultural identities that the source text is meant to defend; recognizing the translation strategies used in this type of text as a means to reflect upon the problems that may arise when silencing voices that stand up for resistance and otherness; examining these findings to highlight a way to recuperate the voices of cultural protest in the translation of LGBT+ literature.

\section{The Translation of Camp}

Sontag's attempt to define the concept of "camp" provided a first approach to its study, but it may have downplayed the queer identity component that other critics reclaimed some thirty years later (see Morrill, 1994; Kleinhans, 1994). Meyer defines camp as the "strategies and tactics of queer parody" $(1994$, p. 9). His ideas may seem outdated nowadays, considering that Meyer maintained that "as specifically queer parody [camp] becomes, then, the only process by which the queer is able to enter representation and to produce social visibility" (ibid., p.11, emphasis added). While it is arguably the only process 
of queer representation today and still dominates much of queer culture in 2019, it certainly preserves "cultural and ideological analytic potential" (Meyer, 1994, p. 10) that requires further commentary in translation studies. As one school librarian told The Associated Press regarding the success of Will Grayson, Will Grayson, "[k]ids have for the most part become 'Will and Grace'-ified," (qtd. in Kehe, 2010, n.p.), recalling the popular NBC network prime-time sitcom Will and Grace, which starting in $1998^{3}$ defied mainstream television in portraying two gay men as protagonists.

The translation of camp still holds and deserves academic interest because of its potential to highlight queer performativity. In the hands of mainstream sensitivities, the queer may be "erased in representation at the very moment that camp is subjected to a dominant interpretation" (Meyer, 1994, p. 13). In that respect, the translator functions as a political agent, for the preservation of hegemonic thought, or the valorization of antihegemonic discourses. If, as Héctor Domínguez Ruvalcaba believes, "[ $t]$ he translation of queer $[\ldots]$ is a political process that involves the recognition of the margins, exclusions, abjections, and oppressions of alternative bodies" (2016, p. 5), the translator can act as a political agent of that recognition. Some postcolonial thinkers such as Kanika Batra have recognized "the limits of Western identity categories, such as gay, lesbian, or queer to describe South Asian sexualities" (2011, p. 95), which would entail overlooking the complexities of Asian societies. This perspective denounces the imposition on the part of Western academia of a different type of colonialism, this time a cultural colonialism which may silence the very voices it aims at showcasing.

However, queer studies in Latin America are not comparable to the predicament of LGBT+ studies in India or other postcolonial countries, or even to those in non-Western countries at large-as they have a different relationship with the plight of recognition of dissident sexualities in society. Illuminating studies such as Brian James Baer's (2017; 2018), James St. André's (2018), or Nour Abu-Assab's (2017) offer insightful analyses that respond to a reality that is distant from that of South America with regard to gender studies. As Domínguez Ruvalcaba explains, "[w] hen the word queer traveled [to Latin America], the trauma of its discriminatory origin stayed at home. It came dressed as a field of study, a political position, an

3. It ran through 2006, and made a comeback in 2017 to great audience success. 
aesthetic proposal, and a lifestyle" (2016, p. 7). Therefore, although Latin America is a continent composed of developing countries, the postcolonial, non-Western analytic tools to study literary texts published there prove inadequate, in the sense that the continent has a vast history of appropriation of queer theories:

Far from undertaking a process of acculturation by transplanting cultural systems and metropolitan theories, Latin Americanist queer scholars and creators translocate discourses and cultural practices between radical Western debates and the troubled realities of the queer Latin American population. (ibid., pp. 3-4)

If we consider that the first LGBT+ movements in Argentina, for instance, were practically born at the same time as the Stonewall riots in New York City, that they have transcended military governments and censorship ${ }^{4}$, and that equal rights marriage was approved in Argentina and Uruguay before it was passed in the United States, it is an error to regard queer studies in the region as a matter of academic imposition or acculturation. They should rather be viewed as a process of adaptation and synthesis in the context of chauvinistic societies. Hegemonic thought persistently attempts to impose mainstream ideas, and the cultural margins have devised their own tools to respond locally. This is why the publication of translations of queer texts demands constant revision.

The translation of camp style in LGBT+ textualities-a style that, as I have pointed out, concerns a large part of Will Grayson, Will Grayson-has been studied by Keith Harvey (2000). According to him, camp is not a cultural sign; rather (in tune with Sontag's views), it works as a form of self-defence against aggression while creating a sense of gay community. Harvey mentions that camp style takes in literature a number of defining features such as the preoccupation with sex (member size, roles or sexual frequency, among others), a fake adherence to conventional moral canons, inversion of gender (such as using feminine terms of endearment for males), queer renaming ${ }^{5}$, foreign language intrusions (especially in French), the construction of a theatricalized woman, hyperbole and exclamation, pop culture

4. With the toll, undoubtedly, of hundreds of LGBT+ individuals who "disappeared" during the last military dictatorships of the 1970s in the region.

5. This is a strategy that Camilo José Cela notes in Spanish literature in his Enciclopedia del erotismo (1976), where he refers to the use of proper names such as Juanita Reina or María Reina in queer slang, where "Reina" means "queen" (Mérida Jiménez and Díaz Fernández, 2013, p. 229). 
intertexts, and a certain linguistic incongruity, i.e., mixing levels of formality and informality, or overlapping high and low language (2000, pp. 449-456). As I have mentioned, many—if not all—of these features make up an integral part of Will Grayson, Will Grayson.

Harvey has undoubtedly been a precursor in the study of queer textualities in translation. His ideas, just like the Canadian school of feminist translators (see Flotow, 1997) and the combination of feminist translation and queer translation in the form of queeriture (see Tsiakalou, 2013), have paved the way for the understanding of translation as a political act. Therefore, studying homoerotic literary discourses from the point of view of camp in translation still holds a key importance:

Translating the language of sex or pleasure, therefore, is not a neutral affair but a political act, with important rhetorical and ideological implications, registering the translator's attitude toward existing conceptualizations of gender/sexual identities, human sexual behavior(s) and moral norms. (Santaemilia, 2018, p. 12)

For that reason, in the case of the novel Will Grayson, Will Grayson, it is important to apply Harvey's model of analysis due to its degree of specificity as well as for certain lexical categories that may not constitute instances of camp language, but which conform interstices which may affect the queer quality of camp.

\section{Will Grayson Green-Levithan-Sobregués}

Will Grayson, Will Grayson was imported from Spain to South America in April 2015, published by Nube de Tinta. It was translated by Noemí Sobregués, and adapted for the region, in the context of the market niche of young-adult literature which had been growing steadily in Argentina (5.5\% yearly since 2011, with a $12 \%$ market share; Blanc, 2016). By June 2015, it occupied the ninth position in the youngadult category of best-sellers in the country (Diario de Cultura, 2015), the largest literary market in the Southern Cone. However, critical response to the novel was varied and sometimes contradictory. While some blogs in Argentina hailed the book because they "couldn't but trust the talent of these two authors" (Weber, 2015; my trans.), others in Chile considered that "[o]nly thanks to the success of The Fault in Our Stars can we understand that we have Will Grayson, Will Grayson" (Costas, 2015; my trans.). Interestingly, while the former review presents its characters as "gay," the latter discusses its "fresh approach to homosexuality" (ibid.; my trans.); both these lexical choices will be 
discussed below. In general, reviews were lukewarm, recommending the book mainly because of the prestige of its authors, or as an original take on the teenage romantic novel. Most critics agreed that it was light reading, and some completely overlooked the fact that it is an LGBT+ book, concealing the very essence of the novel.

Sobregués' translation presents a number of effective decisions regarding the translation of the camp style as defined by Harvey ${ }^{6}$ and considering the two distinct authorial voices. For instance, the preoccupation with sex may be exemplified with the translation of cocksucker (Green and Levithan, 2010a, p. 46) as chupapijas (Green and Levithan, 2015, p. 57), or:

the first thing is we basically make fun of people who have IM sex by inventing our own ridiculous scornographic dialogue.

grayscale: i want you to lick my clavicle.

boundbydad: i am licking your clavicle.

grayscale: ooh my clavicle feels so good.

boundbydad: naughty, naughty clavicle.

grayscale: $\mathrm{mmmmmm}$

boundbydad: wwwwwwww

grayscale: rrrrrrrrrrrrrrrr

boundbydad: ttttttttttttttttttt

(Green and Levithan, 2010a, pp. 69-70)

One notices in the passage above a preoccupation with sex, humor, neologisms, and the characteristic telegraphic style and lower-case punctuation of Levithan's Will Grayson. Noemí Sobregués rendered this passage as:

la primera es que básicamente nos reímos de los que practican sexo por chat inventándonos ridículos diálogos desdeñosos.

6. Sobregués' translation will be studied here from the point of view of its strategies regarding the translation of camp style. However, the version of the novel used in this paper, published by Nube de Tinta, and "adapted for the Rio de la Plata linguistic variety in South America," fails with regards to its dialectal appropriacy, for reasons that I have analyzed elsewhere, but that are mostly irrelevant in this exploration. Nevertheless, it is not incidental from the standpoint of the silencing of voices, as it accounts for the condescending politics of many major publishing houses that force a generally foreign linguistic variety upon much of Latin America on the pretense of inclusion. There will be certain passing references to this issue when the translation becomes ineffective due to this issue. 


\begin{abstract}
escalagrises: quiero que me chupes la clavicula. atadopormipadre: estoy chupandote la clavicula. escalagrises: oooh me encanta. atadopormipadre: una clavicula muy traviesa. escalagrises: hummmmmm atadopormipadre: uuuuuuh escalagrises: rrrrrrrrrrrrrrrrrrr escalagrises [sic]: ttttttttttttttttttt

(Green and Levithan, 2015, pp. 81-82)
\end{abstract}

The translation is effective situationally, with the addition that, in the instant messaging section, it does away with capital letters, and, especially, with the use of accents, a feature that is characteristic of teenagers typing in Spanish and feasible for Levithan's angry young man. The compensation used by translating the neologism scornographic (scornful + pornographic) for a more typically formal word like desdeñoso [disdainful] contributes to the linguistic incongruity of the character's speech, representing another camp feature, and bearing in mind the character's personality.

Similarly, the fake adherence to conventional moral canons is appreciated in "Tiny, you being a makeout whore is so not good for the cause" (Green and Levithan, 2010a, p. 7), translated as "Tiny, que seas una puta que se enrolla ${ }^{7}$ con cualquiera no es bueno para la causa" [Tiny, you being a whore that fools around with anyone is not good for the cause] (Green and Levithan, 2015, p. 13), or later, when Levithan's Tiny starts dating gay Will Grayson and they are in bed, Will exclaims "there's a boy in my bed!" (Green and Levithan, 2010a, p. 212), which, word-by-word, becomes "ihay un chico en mi cama!" (Green and Levithan, 2015, p. 229), applying a humorous, damsel-indistress undertone.

Sobregués has generally been very consistent in her creation of each protagonist's sociolects as a reflection of the authors behind them. Additionally, the translation is profuse in foreign words and expressions, which in the source text is French and in her translation is English: "estoy en el Facebook mirando el perfil de Tiny, echando un

7. This is one of the instances in which the Spanish text can be seen as a peninsular translation that distorts the meaning of the source, since enrollar in South American Spanish means overthink. Nevertheless, this problem is not attributable to the translator, but to a publishing house that simplifies the complexities of dialectal variations for the sake of taking over commercial markets. 
vistazo a sus 1.532 amigos, a cual más guapo y fashion" [I'm on Facebook checking out his 1,532 friends, each hotter and more fashionable than the last] (ibid., p. 50). The choice of English is adequate if we consider the prestige of the language among South American middleclass Spanish-speaking teenagers, although it becomes ineffective in some cases. As I have pointed out, Green's chapters are rich in camp style, unlike Levithan's. However, it is the latter's Will Grayson who uses English words copiously, such as straighthedge or buddy list (ibid., p.37), for example. As these words belong to the lexical field of social networks-Levithan's Will's realm by nature-, they become pragmatically acceptable.

In other sections of the novel, the theatrical overfeminization of women typical of the camp style can be observed. Thus, "you, my dear, are my saturday night plans" (Green and Levithan, 2010a, p. 68) becomes "querido, tu [sic.] eres mi plan para los sabados [sic.] por la noche" [darling, you are my Saturday night plan] (Green and Levithan, 2015, p. 80). Also, when hefty Tiny wants to sing a song from his musical to Levithan's Will, "i am in a completely demolished state. my mind is having a heart attack. the last thing I need is for the fat lady to sing. but do i protest? (Green and Levithan, 2010a, p. 143), it is rendered as "estoy destrozado. me va a dar un infarto cerebral. solo me faltaba la gorda cantando. pero ¿protesto?” [I am demolished. I am about to have a brain seizure. All I needed was the fat lady singing, but do I protest?] (Green and Levithan, 2015, p. 157). In this case, the cultural reference of the platitude "until the fat lady sings" may be lost, as is the Gertrude reference from Hamlet, but there is a certain compensation, not in the idealization of women, but through the feminine name-calling in gorda [fat lady].

While camp is not gay slang per se, it does make use of it in its sex talk, irony, and sarcasm, adherence to heteronormative mores, and feminine name-calling. According to Julia Penelope and Susan J. Wolfe, gay slang corresponds to "specialized uses of language for the purpose of establishing and maintaining cohesion within a special interest group" (1979, p. 3), in this case, gays. In gay slang, a person gains status by devaluing his peers through the use of slurs:

values perpetrated by "gay" slang are those of a heterosexist, patriarchal society in which homophobia is the "norm;" therefore the terms that constitute the "gay" vocabulary serve the interests and expressive needs of males. (ibid.) 
Sobregués' translation makes use of gorda as a demeaning, feminine form of appeal that denigrates Tiny (in Will's mind). This is effective from the point of view of gay slang and camp.

Additionally, linguistic incongruity resulting from the juxtaposition of formal and informal linguistic levels has been generally preserved in the respective sections by both authors, with attention to their nuances, as is the case with gender inversion: "I think Tiny is a fairly cute girl" (Green and Levithan, 2010a, p. 174), which becomes "[c]reo que Tiny es bastante mona" (Green and Levithan, 2015, p. 159). However, Sobregués' translation strategies are not as effective when it comes to queer renaming. Throughout the novel, characters joke and call one another bitchsquealer, a neologistic, feminine slur that the translator opted to translate as zorra chillona [squealing fox] (ibid., pp. 10 and 18, among others). However, zorra chillona is not a neologism in Spanish, and it adds the cunning quality of the fox which is absent in the word bitch. Even though the expression is adequate from the point of view of formal equivalence, it fails dynamically as it misses the undignified, neologistic character of Green's slur.

Among Sobregués' most effective strategies is the translation of Tiny's musical, in which dynamic equivalences outnumber formal equivalences, producing rhymed, entertaining, attractive, and particularly campy songs. It is worth remembering here that musicals represent the essence of camp, in which "there is often something démesuré in the quality of the ambition" (Sontag, 1961, p. 283). Musicals offer a hyperbolic representation of sentimentality, trivialize adversity, and portray life impudently. As mentioned, the novel revolves around the production of Tiny's musical, and its rhymes, its songs-written with teenage hyperbolic sensibility-embody the different features of the camp style as studied by Harvey. It is here where Sobregués, more so than anywhere else, has shown off her craft.

I know from the moment he took top bunk

How desperately I wanted into his trunk

Joseph Templeton Oglethorpe the Third

Left my heart singing like a little bird

Summer of gay!

So lovely! So queer!

Summer of gay!

Set the tone for my year! (Green and Levithan, 2010a, p. 171) 
The gayest anthem of the musical, and one of the theses of the novel itself, "Summer of Gay!", becomes a true song of the LGBT+ youth thanks to Sobregués' abilities:

Supe en cuanto nos metimos en las literas [I knew as soon as we got into the bunks]

que deseaba desesperadamente sus posaderas. [that I desperately wanted his bum]

Joseph Templeton Oglethorpe Tercero [Joseph Templeton Oglethorpe the Third]

Hizo que mi corazón cantara como un jilguero. [made my heart sing like a goldfinch.]

¡Verano gay! [Gay Summer!]

¡Qué bonito! ¡Qué marica! [So lovely! So queer!]

¡Verano gay! [Gay Summer!]

¡Desde ahora mi vida será más rica! [From now on, my life will be richer] (Green and Levithan, 2015, p. 187)

Sobregués applied a series of strategies to preserve meter, rhythm, and rhyme, while maintaining the juvenile freshness and naïveté of the source text: employing the meronym jilguero [goldfinch] for bird, using circumlocutions and repetitions, and resorting to hyperbole in the last line. These strategies allowed her to conserve the parodic, i.e., queer, tone of the song in a successful manner.

Overall, Sobregués has done a very effective work in preserving the dual stylistic aspect of the novel, as well as in most general features of camp discourse, rendering its style adequately. However, she has overlooked other aspects that make the novel queer. In such regard, we are reminded of Meyer's ideas that "[t]he invisible queer subject is an example of such a suppressed and denied area" $(1994$, p. 12). At a time when camp style has largely permeated hegemonic culture ${ }^{8}$, there is a need to revise and reclaim the queer phenomenon of camp, or else "the queer is erased in representation at the very moment that Camp is subjected to a dominant interpretation" (ibid., p. 13). We have seen how certain reviews have erased the LGBT+ component of the novel, and how certain translation choices may have sanitized its queer contents to produce a camp novel "that may or may not be" gay. Even more damaging for the novel itself may be translation instances

8. With TV shows such as RuPaul's Drag Race winning mainstream accolades like the Emmy, and widely publicized events such as the MET Gala of 2019 presenting "camp fashion" as its theme. 
where lexical choices seem to derive from a type of political agency on the part of the translator or the publishing house, that have preserved fossilized negative ideas on homoeroticism.

\section{Objectionable Slurs and Beyond}

In 1978, Alberto Cardín and Biel Mesquida translated FrancoArgentine author Copi's Le bal des folles (1977), and added a five-page appendix glossary which they deemed essential for any heterosexual reader to understand the novel (Mérida Jiménez and Díaz Fernández, 2013, p. 213). This strategy entails an interest in the gay culture as embodied in Copi's work, as much as a preoccupation in finding correspondences to convey a similar effect in the target language. As philosopher Michel Foucault argues:

We must not forget that the psychological, psychiatric, medical category of homosexuality was constituted from the moment it was characterized-Westphal's famous article of 1870 on "contrary sexual sensations" can stand as its date of birth. (1990 [1978], p. 43)

In the late $19^{\text {th }}$ century, psychology gave homosexuality the character of a disease, and the word homosexual is a reminder of this pathologization. It is perhaps for this reason that Green and Levithan's novel uses the term homosexual only twice, and both times ironically. The first time is when Green's Will Grayson jokes about his participation at the Gay-Straight Alliance: "This is the Homosexuality Is An Abomination Club, right?" (Green and Levithan, 2010a, p. 42). The second is when Levithan's Will Grayson befriends another gay young man: "gideon: so, yeah. i heard that you might be, you know.../me: ambidexterous? a philatelist? homosexual?” (ibid., p. 179). Notably, the word comes up only once out of the heterosexual Will of the odd-numbered chapters, and equally so of the gay Will of the evennumbered chapters, in both cases using the word in jest, deriding heteronormative positions.

Considering that Judith Butler has analyzed performative acts as "forms of authoritative speech: most performatives, for instance, are statements that, in the uttering, also perform a certain action and exercise a binding power" (1993, p. 225), I take the word homosexual as a pathologizing performative that derives from a locus of mainstream, heterosexist power. Domínguez Ruvalcaba believes that, in the context of Latin America, "[i]llness and crime are the main excuses and rationales given for the way the state (through its associated apparatuses) stigmatizes queer bodies, ostracizing them and making 
them invisible in the public sphere" (2016, p. 65). For decades in the United States, there has been a debate on the pathologizing connotation of the term homosexual. Similarly, in Latin America, the discussion on the semantic load of the term in Spanish is frequently discussed in the context of the realization that "the heteronormative state uses medical knowledge to keep homosexuality at the margin of the national project" (ibid., p. 67).

As a term, homosexual has come under fire due to what it represents linguistically, i.e., a caricature or a stereotype based on prejudice. There is a wide consensus that the more specific acronym LGBT + better designates the variety in the community. In this sense, Juan Cornejo Espejo advocates for a shift in terminology in the belief that the word homosexual is associated with pathology, deviance, abnormality, and perversion; it underlines the fact that there is an alleged organic or psychological homosexual substance common to all people with homoerotic tendencies, and it is used as a form of symbolic domination, i.e., an imposition of worldviews and socially legitimized representations (2007, pp. 98-99). While that may not have been the case in Spain ${ }^{9}$, Latin America has profited from social movements occurring in the First World, adapting ideas and campaigns as considered appropriate. "LGBT activism came from metropolitan countries as a liberation movement; it is part of the paradoxes of the postcolonial condition" (Domínguez Ruvalcaba, 2016, p. 13).

In that sense, then, it is noticeable that Sobregués makes extensive use of homosexual and its derivatives in her translation of this LGBT+ novel. In fact, she offers it as an equivalent for gay: "cuando se dedicó a descubrir el verdadero alcance de su homosexualidad [gayness]" (Green and Levithan, 2015, p. 9; my italics); "la quizás homosexual [possibly gay] Jane" (ibid., pp. 17,21, and 24; my italics); "Exacto - le dice a Jane -. Sabes lo duro que es porque eres... Ah, espera. Está bien. Tú no eres homosexual [gay]" (ibid., p. 56; my italics). In this way, the translation fossilizes the pathologization of the gay identity for the younger generations of readers. This fact undermines the LGBT+ character of the novel, and jeopardizes the political ideas of its authors (judging for their use of language). In it original version, Will Grayson, Will Grayson is a novel that has been granted an ALA Stonewall Honor award for LGBT+ literature. In its adaptation to South American readerships,

9. Due to the centrality of the country as a European, colonial power and Franco's dictatorship that ostracized the country for the better part of the $20^{\text {th }}$ century (from 1939 to 1975$)$. 
the pathologization of the sexual identity of many of its characters has gone unnoticed by the translator or by the publishing house, endangering the very ideas the novel is meant to transmit.

Butler has theorized on the term queer and the heteronormative load it may have outside of the LGBT+ community:

When the term has been used as a paralyzing slur, as the mundane interpellation of pathologized sexuality, it has produced the user of the term as the emblem and vehicle of normalization; the occasion of its utterance, as the discursive regulation of the boundaries of sexual legitimacy. (1993, p. 223)

In the same way as the pathologizing tag homosexual, Sobregués' translation extensively uses the strong, demeaning slur puto [faggot], which is inexistent in the source text. In that respect, the use of a term with such a pejorative, incendiary, and devaluing load becomes pernicious for a committed LGBT+ young-adult work. Throughout the Spanish version of the novel, puto is repeatedly used as an intensifier. For example, it becomes the equivalent of goddamn, fucking, frakking, or dumbass. While some may argue that it is not uncommon to find this slur within the LGBT+ community-which would thus make it acceptable for the translator to use it here-, mainstream society largely uses it belittlingly. Mary Louise Pratt's contact model of language considers that speakers "constitute each other relationally and in difference" (qtd. in Harvey, 2000, p. 447), which entails the ineffectiveness of this reappropriated word in a mainstream book dealing with LGBT+ issues geared toward larger readerships.

It is important to note here that Peninsular Spanish may use the word puto extensively as an emphasizer. However, our analysis here focuses on the novel as it was adapted to Southern Cone readerships, i.e., Argentina, Bolivia, Chile, Paraguay, and Uruguay. The novel thus fails to provide an alternative array of emphasizers which may have avoided the slur. In this case, the translation of Will Grayson, Will Grayson confirms Tison Pugh's belief that "building homosexuality as a normative enactment of sexual desire within children's fiction requires overcoming even greater ideological obstacles" (2011, p. 162). Whether those obstacles be the lack of consideration for the target readership market in South America, the inherence of heterosexist language in the translation, the lack of empathy for LGBT+ readers, the overlooking of the pedagogic intent of the novel, the preservation of mainstream values, the intrusion of hegemonic ideas, or a com- 
bination of these factors, the resulting product seems to disregard the values it aims to cherish:

Gay fiction for children and adolescents provides a necessary alternative to a literary landscape that often overlooks homosexuality, yet ironically, antigay ideology triumphs even within many of these texts when they depict homosexuality as a problem to be overcome rather than as an identity to be celebrated. (ibid.)

Young-adult novels fulfill a certain didactic purpose, not akin to that of children's literature. Nitsa Ben-Ari has studied the translation of children's literature from German to Hebrew in the postwar period, and described operational norms whose application aims at making the text acceptable for the target readers from the point of view of their didactic purpose. Some of these norms include "repetition-cancelling norms, addition and omission norms [...] and various conversion norms" (Ben-Ari, 1992, p. 223). The author advises avoiding repetition in children's texts, as it does not help the readers enhance their vocabulary; instead, she fosters the use of synonymy. Additions are to be freely applied, especially for teaching purposes, including "elements of amplification," such as pragmatic connectives or idiomatic expressions, and "explication elements" to clarify expressions for the sake of better comprehension (ibid., p. 277). In this way, considering Judith Butler's notions of the devaluing effect of performatives, Rafael Mérida Jiménez and Estrella Díaz Fernández's ideas of annotations or a glossary might have proven more effective in light of Ben-Ari's didactic purpose of this literature, as the translated version of the book does not live up to the expectations of queer criticism today. On the contrary, it becomes possibly pernicious for the psyche of young adults.

Finally, other decisions have been taken by the translator in the construction of the heterosexual Will Grayson by Green that may insinuate him as gay. For instance, in chapter five, Will is "más helado que la teta de una bruja con sujetador metálico" (Green and Levithan, 2015, p. 86 ${ }^{10}$. His identification with a female archetypeas opposed to the generic weather reference of the source text-adds an unnecessary feminizing effect. Later, Will wonders if he should not perhaps become "drogadicto y practicar sexo sin protección con ochenta $y$ siete desconocidos" (Green and Levithan, 2015, p. 88; emphasis

10. The passage reads like this in the original: "it's colder than a witch's tit in a steel bra" (Green and Levithan, 2010, p. 74). 
added) [develop a meth addiction and have unprotected sex with eighty-seven thousand anonymous partners" (Green and Levithan, 2010, p. 76; emphasis added)]. Beyond the hyperbolic loss, the decision to use the Spanish generic masculine for a straight character complexifies the character formation from the point of view of his identity, as it places him in a locus of bisexuality. Subsequently, Clint, a member of Will's old clique, greets him with the word cabrón [fucker], which makes Will ponder on its intention: “¿Es un piropo? ¿Un insulto?" (Green and Levithan, 2015, p. 90). In the source text, Will wonders whether Clint's greeting is a "compliment" (Green and Levithan, 2010, p. 77), a marker of cordiality rather than a heterosexist pick-up line stereotypically for a woman, which is what piropo means. These examples, among others, contribute to Will's sexual indeterminacy, which may puzzle readers and construct an inexistent character with homoerotic desire, possibly perpetuating negative stereotypes in LGBT+-heterosexual relationships (Hocquenghem, 2009 [1972]).

The use of the word homosexual, the instances of puto as an emphasizer, and the construction of a heterosexual character as sexually fluid are three examples of how translation decisions may undermine the foundations of the LGBT+ novel.

\section{Conclusions}

When Keith Harvey wrote his seminal article on the translation of camp, he indicated that "many more instances of camp talk call for description in order to bring out the trends" (2000, p. 446). In that sense, this article has presented an analysis in view of the lack of empowerment of LGBT+ groups, whose ideas have often been silenced in translation, sometimes because of the notion that camp is not a solely queer critique practice. The core of this perspective centers on key concepts such as the right to identity, access to knowledge, visibility, and freedom of expression. This analysis has found that focusing on Harvey's ideas on camp translation is necessary for the translation of LGBT+ textualities, but that it is insufficient considering the queer power of cultural critique of camp:

Often considered frivolous, aestheticized, and apolitical, the discourse of Camp can be reclaimed through a rereading of the phenomenon as a signifying practice that not only processually constitutes the subject, but is actually a vehicle for an already existent-though obscured-cultural critique. (Meyer, 1994, p. 12) 
While Sobregués' translation has generally respected and maintained the camp style in the Spanish version of Will Grayson, Will Grayson and worked effectively on the discursive conformation of the two authorial voices, there are issues related to patriarchal, heterosexist language that overlook LGBT+ desire and sexual dissidence, i.e., the politically loaded aspects of camp. ${ }^{11}$ Because of its tremendous popularization in mainstream, hegemonic society, camp runs the risk of being assimilated, and stripped of its queer, critical aspects. Some twenty years after the publication of Harvey's article, camp needs to be reclaimed, revalued, and reconstituted as queer parody. It is also necessary to set up other parameters for the analysis of translations that not only regard specific technical matters stylistically, but go deeper into heteronormative intrusions that may leak into the translation of LGBT+ literature.

Sobregués offers numerous wise decisions with regard to the translation techniques used. Nonetheless, a more profound study of the target text unearths deeply rooted identity issues that undermine the effective strategies of the surface level, issues that may well respond to directives or policies of a publishing house that imposes the adaptations of its translation to South America in a contemporary form of neocolonialism. Additionally, the role of the translator as a political agent in the political process that constitutes translation surfaces. Translators may willingly work for the preservation of hegemonic values, or simply overlook the manner in which heteronormative ideas permeate their practice. Regardless of the reason, the political role of the translator thus becomes one that is instrumental to mainstream values. By contrast, the understanding of camp discourses as queer parody may offer a different outlook of the political process of translation and foster strategies to queerify it. Terry Lovell has reflected on the subversive power in the recognition of queer in the dominant culture:

there are key areas of experience and practical activity which are suppressed, denied, and distorted within dominant ideology. While their suppression makes it difficult to give them a name, and to understand their significance, they are essential to knowledge production and to the critique of ideology. (qtd. in Meyer, 1994, p. 12)

These liabilities inhibit the translation and are potentially detrimental for the collective imagination. Literary translation from the cultural

11. I reached out to Sobregués and the publishing house to discuss some of these issues, but they were not available for comment. 
margins is necessary in translation studies to broaden our perspectives, and better understand that the cosmovision of many depends, in part, on our job. The case of Will Grayson, Will Grayson is a case of the reedition, and therefore the re-affirmation, of mainstream, heterosexual, patriarchal thought in matters pertaining to the LGBT+ ideas that the source text it meant to convey. Cultural margins demand further study in the use of effective translation strategies so as not to silence the very voices that other literary systems aim to communicate.

\section{References}

Abu-Assab, Nour (2017). "Queering Narratives and Narrating Queer: Colonial Queer Subjects in the Arab World.” In B.J. Epstein and R. Gillett, eds. Queer in Translation. New York and London, Routledge, pp. 25-36.

Baer, Brian James (2017). "A Poetics of Evasion: The Queer Translations of Aleksei Apukhtin.” In B.J. Epstein and R. Gillett, eds. Queer in Translation. New York and London, Routledge, pp. 51-63.

Baer, Brian James (2018). "Beyond Either/Or. Confronting the Fact of Translation in Global Sexuality Studies.” In B. J. Baer and K. Kaindl, eds. Queering Translation, Translating the Queer Theory, Practice, Activism. New York and London, Routledge. pp. 38-57.

Batra, Kanika (2011). Feminist Visions and Queer Futures in Postcolonial Drama. Community, Kinship, and Citizenship. New York and London, Routledge.

Ben-Ari, Nitsa (1992). "Didactic and Pedagogic Tendencies in the Norms Dictating the Translation of Children's Literature: The Case of Postwar German-Hebrew Translations.” Poetics Today, 13, 1, pp. 221-230.

Blanc, Natalia (2016). "Literatura infantil y juvenil: creció un 15\% la niña bonita de la industria editorial.” La Nación, 3 August. [https://www.lanacion.com. ar/cultura/literatura-infantil-y-juvenil-crecio-un-15-la-nina-bonita-de-laindustria-editorial-nid1924245].

Bronski, Michael (2000). The Pleasure Principle, Sex, Backlash, and The Struggle for Gay Freedom. New York, Stonewall Inn Editions.

Butler, Judith (1993). Bodies that Matter. On the Discursive Limits of Sex. New York and London, Routlegde.

Cornejo Espejo, Juan (2007). "La homosexualidad como una construcción ideológica." Limite. Revista de Filosofía y Psicología. 16, 2, pp. 83-108.

Costas, Rodrigo (2015, 15 July). "Muchachos de hoy: las nuevas novelas juveniles.” La Fuente. [https://www.fundacionlafuente.cl/muchachos-dehoy-las-nuevas-novelas-juveniles].

Diario De Cultura (2015). "Los libros infantiles y juveniles más vendidos." [https://www.diariodecultura.com.ar/rankings/los-libros-infantiles-yjuveniles-mas-vendidos/].

Domínguez Ruvalcaba, Héctor (2016). Translating the Queer: Body Politics and Transnational Conversations. London, Zed Books. 
Editorial Staff (2016). "A Note from the Editors.” The Daily Beast. 11 August. [https://www.thedailybeast.com/a-note-from-the-editors? source=twitter \&via=desktop].

Flotow, Luise von (1997). Translation and Gender: Translation in the "Era of Feminism." Ottawa, University of Ottawa Press.

Foucault, Michel (1990 [1978]). The History of Sexuality. Volume 1: An Introduction. Trans. R. Hurley. New York, Random House.

Green, John and David Levithan (2010a). Will Grayson, Will Grayson. New York, Speak.

Green, John and David Levithan (2010b). "A Conversation between John Green and David Levitan." In J. Green and D. Levithan. Will Grayson, Will Grayson. New York, Speak.

Green, John and David Levithan (2015). Will Grayson, Will Grayson. Trans. Noemí Sobregués, Barcelona, Nube de Tinta.

Harvey, Keith (2000). "Translating Camp Talk. Gay Identities and Cultural Transfer." In L. Venuti, ed. The Translation Studies Reader. London and New York, Routledge. pp. 446-467.

Hocquenghem, Guy (2009 [1972]). El deseo homosexual. Trans. G. H. de la Marre. Santa Cruz de Tenerife, Melusina.

Hogan, Paul (1997). My Best Friend's Wedding. TriStar Pictures.

Kehe, Marjorie (2010). "Gay-themed Novels for Young Readers Enter the Mainstream." The Christian Science Monitor. 24 June. [https://www. csmonitor.com/Books/chapter-and-verse/2010/0624/Gay-themednovels-for-young-readers-enter-the-mainstream].

Kleinhans, Chuck (1994). "Taking out the Trash: Camp and the Politics of Parody." In M. Meyer, ed. The Politics and Poetics of Camp. London and New York, Routledge, pp. 182-201.

Mérida Jiménez, Rafael M. and Estrella Díaz Fernández (2013). "Los diccionarios ante el argot 'gay' en España (1970-1984)." In N. Vila Rubio, ed. De parces y troncos. Nuevos enfoques sobre los argots hispánicos. Lérida, Edicions de la Universitat de Lleida, pp. 209-230.

Meyer, Moe (1994). "Introduction: Reclaiming the Discourse of Camp." In M. Moyer, ed. The Politics and Poetics of Camp. London and New York, Routledge, pp. 1-22.

Morrill, Cynthia (1994). "Revamping the Gay Sensibility." In M. Meyer, ed. The Politics and Poetics of Camp. London and New York, Routledge, pp. 110129.

Penelope, Julia and Susan J. Wolfe (1979). "Sexist Slang and the Gay Community: Are You One, Too?"Women's Studies Program, ed. Michigan Occasional Papers on Women's Studies. [http://hdl.handle.net/2027/spo. aaf0222.0014.001:02].

Pugh, Tison (2011). Innocence, Heterosexuality and the Queerness of Children's Literature. London and New York, Routledge. 
Santaemilia, José (2018). "Sexuality and Translation as Intimate Partners? Toward a Queer Turn in Rewriting Identities and Desires." In B. J. Baer and K. Kaindl, eds. Queering Translation, Translating the Queer. Theory, Practice, Activism. New York and London, Routledge, pp. 11-25.

Sontag, Susan (1961). “Notes on Camp." In S. Sontag, Against Interpretation and Other Essays. New York, Picador, pp. 275-292.

St. André, James (2018). "In All His Finery: Frederick Marryat's The Pacha of Many Tales as Drag." In B. J. Baer and K. Kaindl, eds. Queering Translation, Translating the Queer. Theory, Practice, Activism. New York and London, Routledge, pp. 84-95.

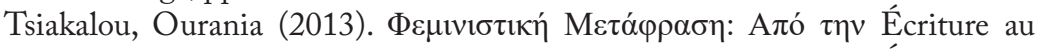

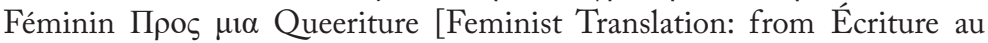
Féminin towards Queeriture]. [https://www.frl.auth.gr/sites/4th_trad_ congress/pdf/tsiakalou.pdf].

Weber, Ximena (August 2015). "Reseña: 'Will Grayson, Will Grayson.” Un millón de emociones. [https://unmillonde-emociones.blogspot.com/2015/08/ resena-will-grayson-will-grayson.html].

Woodley, Shailene (2014). "John Green. The 100 Most Influential People." Time Magazine. 23 April. [https://time.com/collection-post/70799/johngreen-2014-time-100/].

\author{
Guillermo Badenes \\ Facultad de Lenguas \\ Universidad Nacional de Córdoba \\ Córdoba, Argentina \\ guillermo.badenes@unc.edu.ar
}

